Juliana Gabrielle Martins-Oliveira ${ }^{1}$

Kelly Oliva Jorge ${ }^{1}$

Raquel Conceição Ferreira ${ }^{2}$

Efigênia Ferreira e Ferreira ${ }^{2}$

Míriam Pimenta Vale ${ }^{1}$

Patrícia Maria Zarzar $^{1}$

\title{
Risk of alcohol dependence: prevalence, related problems and socioeconomic factors
}

\author{
Risco de dependência do álcool: \\ prevalência, problemas relacionados e fatores socioeconômico
}

${ }^{1}$ Departamento de

Odontopediatria e

Ortodontia, Universidade

Federal de Minas Gerais

(UFMG). Av. Pres.

Antônio Carlos, 6627,

Pampulha. 31270-901 Belo

Horizonte MG Brasil.

julianagabrielle@

hotmail.com

Abstract The present study evaluated the possible alcohol dependence and related problems among adolescents and determined possible associations with socioeconomic factors and gender. A cross-sectional study was conducted with a representative sample of 936 adolescents aged 15 to 19 years enrolled at public and private schools in the city of Belo Horizonte, Brazil. Data related to alcohol consumption and associated problems were collected using the Alcohol Use Disorder Identification Test (AUDIT). The Social Vulnerability Index (SVI), mother's schooling and type of school were used to assess socioeconomic factors. Statistical analysis involved the chi-square test ( $p$ $<0.05$ ) and Poisson regression. The prevalence of possible dependence was $16.4 \%$, 52.1\% reported concern of a family member regarding the adolescent's alcohol consumption. Female adolescents were less likely to exhibit possible dependence in comparison to males. Participants with living in a low vulnerability area were more likely to consume alcohol in comparison to those living in underprivileged areas. The results of the present study demonstrate that possible dependence was significantly associated with the male gender and low social vulnerability.

Key words Adolescents, Alcohol consumption, School health, Epidemiology, Socioeconomic factors
Resumo O presente estudo avaliou a possivel dependência de álcool e problemas relacionados entre adolescentes e determinou possíveis associações com fatores socioeconômicos e de gênero. Foi realizado um estudo transversal com uma amostra representativa de 936 adolescentes, com idades entre 15 a 19 anos, matriculados em escolas públicas e privadas da cidade de Belo Horizonte, Brasil. Os dados relativos ao consumo de álcool e aos problemas relacionados foram coletados utilizando o Alcohol Use Disorder Identification Test (AUDIT). O Índice de Vulnerabilidade Social (IVS), a escolaridade da mãe e o tipo de escola foram utilizados para avaliar os fatores socioeconômicos. A análise estatística envolveu o teste do qui-quadrado ( $p<$ $0,05)$ e a regressão de Poisson. A prevalência de possível dependência foi de 16,4\%. Relataram preocupação de um familiar em relação ao consumo de álcool do adolescente, 52,1\%. As mulheres foram menos propensas a apresentar possivel dependência em relação aos homens. Adolescentes que vivem em uma área de baixa vulnerabilidade foram mais propensos a consumir álcool em comparação com aqueles que vivem em áreas carentes. Os resultados demonstram que a possivel dependência foi significativamente associada com o sexo masculino e com a baixa vulnerabilidade social.

Palavras-chave Adolescentes, Consumo de álcool, Saúde escolar, Epidemiologia, Fatores socioeconômicos 


\section{Introduction}

According to the World Health Organization, alcohol is the most widely consumed psychoactive substance in the world and is the drug of choice among children and adolescents. International studies report alcohol consumption prevalence rates ranging from $3.9 \%$ to $51.6 \%^{1,2}$. A systematic review, involving adolescents aged 10-19 years, carried out in Brazil detected prevalence rates of current alcohol use ranging from $23.0 \%$ to $67.7 \%$. The prevalence observed may be due to differences in the methodologies employed and sample characteristics. As the positive association between age and alcohol demonstrates that alcohol abuse generally starts during adolescence and tends to escalate in adulthood, researchers have emphasized the importance of evaluating consumption patterns among adolescents $^{4-6}$. Therefore, studies that evaluate this consumption and associated factors are important. Different fields of scientific knowledge adopt different definitions for the terms "use", "abuse" and "dependence". The International Classification of Diseases defines "use" as any amount of consumption regardless of frequency; "abuse" is considered consumption associated with recurring adverse consequences and "dependence" is considered consumption that characterizes a dysfunctional state ${ }^{7}$. Individuals with an alcohol consumption pattern considered hazardous or abusive should be encouraged to seek to eliminate or reduce their alcohol intake, whereas those with suspected dependence should be sent to specialized services for a confirmation of the diagnosis and treatment ${ }^{8}$.

Alcohol abuse increases the risk of a series of social and health problems, including frustrated attempts to stop drinking, violence and unintentional injuries, with repercussions for both physical and mental health ${ }^{9}$. Psychological consequences include learning difficulties, memory loss and feelings of guilt or remorse following alcohol consumption ${ }^{5}$. A survey involving adolescent students aged 10 to 18 years reports that regular use of alcoholic beverages may begin as early as 10 years of age ${ }^{6}$. When early experimentation is carried out can lead to worse consequences and a greater risk for the development of dependence ${ }^{10,11}$.

Failed law enforcement combined with the risk taking and impulsive tendencies that are intrinsic to adolescence make this large portion of the population more vulnerable than the adult population to addiction and in need of special attention. Understanding the underlying factors associated with use of alcohol among adolescents is essential to the establishment of early intervention strategies, which are crucial to preventing substance use disorders and the negative impacts on adult life ${ }^{4,5}$.

A large number of articles report prevalence rates of alcohol consumption and the risk of dependence among adolescents ${ }^{1,12,13}$. However, there is a need for additional studies that also address the consequences and problems related to alcohol consumption and the possible dependence in this group as well as associations with socioeconomic aspects. A number of investigations have demonstrated an association between residence in less socially vulnerable areas (more advantageous conditions) and greater alcohol consumption among adolescents in comparison to those who live in areas of greater social vulnerability ${ }^{12-14}$. While others report positive associations between low socioeconomic status and high-risk alcohol drinking ${ }^{15,16}$. However, some studies have found that alcohol consumption is negatively associated with socioeconomic status. Thus, conflicting results are found regarding the association between alcohol consumption and socioeconomic status among adolescents needs to be clarified. Such information can contribute to the implementation of more effective public health policies. The aim of the present study was to evaluate the prevalence, frequency, possible alcohol dependence and related problems, and determine possible associations with socioeconomic factors and gender among adolescent students in the city of Belo Horizonte, state of Minas Gerais, Brazil.

\section{Materials and methods}

\section{Sample characteristics}

A cross-sectional study was carried out with a representative sample of 936 adolescents between 15 and 19 years of age enrolled in public and private schools in the city of Belo Horizonte between August 2009 and February 2010. Belo Horizonte is the capital of the state of Minas Gerais (southeastern Brazil). The city has approximately 2.4 million inhabitants and is geographically divided into nine administrative districts (Brazilian Institute of Geography and Statistics, 2010) ${ }^{17}$. A total of 117,547 and 25,569 15-to-19-year-old students are enrolled in 820 public and 434 private schools, respectively ${ }^{18}$. A full list of all students enrolled in public and private schools was 
obtained from the Belo Horizonte Secretary of Education and the distribution of students in each of nine administrative districts was calculated.

To represent the real distribution of 15-to19-year-old students in Belo Horizonte, twostage stratified cluster sampling was used proportional to the administrative districts. The first stage was the random selection of two schools in each of the nine districts (total of 18 schools). Three public schools refused to participate due to time constraint linked to previous teachers' strike that year and were replaced by others through an additional random selection by lots. The second stage was the random selection of 34 classrooms from the 65 classrooms in the 18 schools. The sample size was calculated based on $4.0 \%$ standard error, $95.0 \%$ confidence interval, and 50\% prevalence rate of illicit drug use. The minimum sample size required was determined to be 600 individuals, to which $20.0 \%$ was added to compensate for possible non-responses $(n=720)$. A design effect of 1.3 was applied to increase the precision, as multistage sampling was employed rather than simple random sampling ${ }^{19}$. Thus, the sample was comprised of 936 adolescents. The test power was $80.0 \%$.

\section{Data acquisition}

The self-administered Alcohol Use Disorders Identification Test (AUDIT) and a form with items on address, age, gender and mother's schooling were distributed in the classroom by a researcher and an assistant, who gathered the material immediately after the questionnaires were filled out. The students were told that the questionnaire would be anonymous and the responses would be treated confidentially. To ensure the comprehension of the questionnaire among students with different levels of reading proficiency, the principal investigator (K.O.J.) read each question aloud.

\section{Assessment of alcohol consumption}

AUDIT is a simple method for measuring the excessive consumption of alcoholic beverages and consists of 10 questions on recent alcohol consumption (12 months preceding the survey), symptoms of dependence and problems related to alcohol use. Each response receives a score ranging from 0 to 4 , with the total score ranging from 0 to 40 points. A score of 7 points or less denotes abstinence or low risk use; scores of 8 to 15 denote hazardous use; scores of 16 to 19 denote harmful use and scores of 20 to 40 denote possible dependence $^{20}$. In the present study, the score was dichotomized as 7 points or less (low risk) and 8 points or more (hazardous use to possible dependence). Based on the original instrument ${ }^{21}$ and a validation study ${ }^{20}$, a cutoff point of 7 was adopted. Scores above this cutoff point denoted hazardous use to possible alcohol dependence. A score of 7 or lower denoted abstinence or a low risk use. Based on the first question on the questionnaire ("How often Do you have did a drink containing alcohol in the past year?") the prevalence of alcohol consumption was established. Responses of "never" were coded 0 in the analysis; responses of one to four times a month to two or more times a week were coded 1 . The first question was also used to determine the frequency of alcohol intake. Responses of "never" were coded 0 in the analysis; responses of one to four times a month were coded 1 and responses of two or more times a week were coded 2.

\section{Assessment of socioeconomic factors}

The Social Vulnerability Index (SVI) was used for the socioeconomic classification. The SVI measures social exclusion in the city of Belo Horizonte. The city hall database of SVI scores for each district was used in the present study based on the address of each individual (Belo Horizonte City Hall, 2009) ${ }^{22}$. This index is an ecological indicator composed of 20 variables grouped into five "dimensions of citizenship": environmental (access to housing and basic infrastructure); cultural (access to education); economic (access to income and employment); juridical (access to legal assistance); and survival security (access to health, food security and welfare ${ }^{23}$. The SVI has often been used in studies carried out in the city of Belo Horizonte ${ }^{14}$. The final score ranges from 0 and 1 , with a higher score denoting that the community in question is more vulnerable to social exclusion. For the statistical analysis, the SVI was dichotomized as high social vulnerability (classes I and II) and low social vulnerability (classes III, IV and V), where the class I represent the class with larger social exclusion and class $\mathrm{V}$ to lower social exclusion.

Mother's schooling was chosen as an individual socioeconomic indicator due to its association with "heavy drinking"24. This variable was determined based on the responses of the participants regarding the years of study their respective mothers had. Adolescents who reported that their mothers studied from zero to seven years were coded 0 and those who reported eight or 
more years were coded 1 . The cutoff point was based on the median.

Type of school was also used as a socioeconomic indicator. Although type of school is a crude assessment, wealthy adolescents in Brazil are enrolled in private schools, because most Brazilian public schools are known to have fewer educational resources. Moreover, Brazilian national epidemiological studies and others studies carried out in cities in southeastern Brazil have used this variable as an indicator of socioeconomic status ${ }^{14,25}$. A recent study concluded that type of school is a useful socioeconomic indicator in studies involving Brazilian children ${ }^{26}$.

\section{Statistical analysis}

In the case of complex sample, estimates of prevalence and confidence intervals were calculated using the module "Complex Sample", the Statistical Package for the Social Sciences (SPSS), which considers the study design and weights sample. The sample weights were calculated for each individual by calculating the inverse of the probability of inclusion of each individual in the study. The probability was obtained by multiplying the inclusion probabilities in the stages of random selection (schools and rooms) and the response rate.

To evaluate the factors associated with the use of alcohol was performed bivariate analysis (chisquare test) and Poisson regression. Initially, the crude analysis was made as a criterion for inclusion in the models mutiplos a value of $p \& \# 8804$ 0.20 . Multiple regression analysis was performed using Stata 11.0-2009 program, considering the complex sampling plan and sample weights (svyset command).

\section{Ethical considerations}

This study received approval from the $\mathrm{Hu}$ man Research Ethics Committee of the Universidade Federal de Minas Gerais - Brazil. Authorization was obtained from the administrators of the participating schools. Parents/guardians and the adolescents themselves signed a statement of informed consent. The participants were ensured anonymity and confidentiality in their responses.

\section{Results}

The final sample was made up of 891 adolescents between 15 and 19 years of age enrolled at public and private schools in the city of Belo Horizonte, Brazil. The loss rate was $4.8 \%$ (45 adolescents) due to the incomplete filling out of the questionnaires. The prevalence of alcohol consumption was $46.9 \%$, with the frequency ranging from once of month to two or more times a week. One hundred fifty-eight students (16.4\%) demonstrated hazardous use to possible dependence (Table 1).

Table 2 displays the distribution of the sample according to the independent variables in relation to the dependent variable (hazardous use to possible dependence). Adolescents less socioeconomically vulnerable have higher prevalence of hazardous use to possible dependence of alcohol $(\mathrm{p}=0.044)$ than those more socioeconomically vulnerable (class I and II).

Among adolescents who reported consequences of alcohol consumption, the most frequently reported consequences of alcohol use,

Table 1. Sample characteristics; Belo Horizonte, Minas Gerais, Brazil, 2010.

\begin{tabular}{|c|c|}
\hline Characteristics & $\begin{array}{l}\% \text { fixed } \\
(95 \% \text { IC })\end{array}$ \\
\hline \multicolumn{2}{|l|}{ Gender } \\
\hline Male & $40.4(35.2-45.7)$ \\
\hline Female & $59.6(54.3-64.8)$ \\
\hline \multicolumn{2}{|l|}{ Age (dichotomized by mean) } \\
\hline 15 to 16 & $54.4(37.0-70.8)$ \\
\hline 17 to 19 & $45.6(29.2-63.0)$ \\
\hline \multicolumn{2}{|l|}{ Type of school } \\
\hline Public & $94.2(79.9-98.5)$ \\
\hline Private & $5.8(1.5-20.1)$ \\
\hline \multicolumn{2}{|l|}{ Mother's schooling (years of study) } \\
\hline 0 to 7 & $57.0(44.5-68.7)$ \\
\hline 8 or more & $43.0(31.3-55.5)$ \\
\hline \multicolumn{2}{|l|}{ Social Vulnerability Index } \\
\hline $\begin{array}{l}\text { High vulnerability (Classes I } \\
\text { and II) }\end{array}$ & $72.1(44.4-89.4)$ \\
\hline $\begin{array}{l}\text { Low vulnerability (Classes III, } \\
\text { IV and V) }\end{array}$ & $27.9(10.6-55.6)$ \\
\hline \multicolumn{2}{|l|}{ Frequency of alcohol consumption } \\
\hline Never & $53.1(48.1-58.0)$ \\
\hline 1 to 4 times a month & $37.9(34.1-41.9)$ \\
\hline 2 or more times a week & $9.0(6.6-12.1)$ \\
\hline \multicolumn{2}{|l|}{ * Possible alcohol dependence } \\
\hline Hazardous use to possible & $83.6(74.8-89.7)$ \\
\hline
\end{tabular}

'Possible alcohol dependence. Abstinence to low risk use ( $\leq 7$ /audit score). Hazardous use to possible dependence ( $\geq 8$ /audit score) 
once a week to nearly every day, were the concern of a family member or friend regarding the adolescent's alcohol consumption or the suggestion that he/she stop drinking (52.1\%), a feeling of guilt or remorse for having drunk $(28.7 \%)$ and the cause injury or harm to yourself or others (28.1\%) (Table 3).

Table 4 displays the results of the multivariate Poisson regression analysis regarding the dependent variable (hazardous use to possible dependence) and independent variables. Female adolescents were less likely to exhibit hazardous use to possible dependence in comparison to males (adjusted RR: 0.75; 95\% CI: 0.54 to 1.0$)$. Participants from areas of low social vulnerability (those with a higher socioeconomic status) were more likely to exhibit hazardous use to possible dependence in comparison to those who lived in less privileged areas (adjusted RR: 2.80; 95\% CI: 1.14 to 2.15 ).

\section{Discussion}

Due to the frequent harm caused to one's health, the abusive consumption of alcohol among adolescents is an important public health issue. Despite the prohibition of the sale of alcoholic beverages to minors (Law no 9.294 , July 15,1996$)^{27}$,
Table 3. Distribution of sample of adolescents who reported to consume alcohol beverage in the last year according to consequences of this alcohol consumption, Belo Horizonte, Minas Gerais, Brazil, 2010.

\begin{tabular}{|c|c|}
\hline $\begin{array}{l}\text { Consequences related } \\
\text { to alcohol use }\end{array}$ & $\begin{array}{l}\text { Estimate } \\
(95 \% \mathrm{CI})\end{array}$ \\
\hline \multicolumn{2}{|l|}{ Frustrated attempt to stop drinking } \\
\hline Once a month or less & $79.4(75.3-83.1)$ \\
\hline Once a week to nearly every day & $20.6(16.9-24.7)$ \\
\hline \multicolumn{2}{|l|}{ Failure to do what was expected } \\
\hline Once a month or less & $81.4(73.7-87.3)$ \\
\hline Once a week to nearly every day & $18.9(12.7-26.3)$ \\
\hline \multicolumn{2}{|l|}{$\begin{array}{l}\text { Need to drink in the morning to } \\
\text { feel better }\end{array}$} \\
\hline Once a month or less & $90.8(83.3-95.1)$ \\
\hline Once a week to nearly every day & $9.2(4.9-16.7)$ \\
\hline \multicolumn{2}{|l|}{ Guilt or remorse for having drunk } \\
\hline Once a month or less & $71.3(56.7-82.5)$ \\
\hline Once a week to nearly every day & $28.7(17.5-43.3)$ \\
\hline \multicolumn{2}{|l|}{ Inability to recall something } \\
\hline Once a month or less & $81.4(68.9-89.7)$ \\
\hline Once a week to nearly every day & $18.6(10.3-31.1)$ \\
\hline \multicolumn{2}{|l|}{$\begin{array}{l}\text { Concern of family member/friend } \\
\text { or suggestion to stop drinking }\end{array}$} \\
\hline Once a month or less & $47.9(40.3-55,5)$ \\
\hline Once a week to nearly every day & $52.1(44.5-59.7)$ \\
\hline \multicolumn{2}{|l|}{ Injury or harm to yourself or others } \\
\hline Once a month or less & $71.9(60.8-80.8)$ \\
\hline Once a week to nearly every day & $28.1(19.2-39.2)$ \\
\hline
\end{tabular}

Table 2. Distribution of sample according to independent variables and prevalence of hazardous use to possible dependence; Belo Horizonte, Minas Gerais, Brazil, 2010

\begin{tabular}{|c|c|c|c|}
\hline \multirow[b]{2}{*}{ Independent variables } & \multicolumn{3}{|c|}{$\begin{array}{l}\text { Hazardous use to possible dependence } \\
\text { ( } \geq 8 \text { /AUDIT SCORE) }\end{array}$} \\
\hline & $\begin{array}{l}\text { No } \\
\%\end{array}$ & $\begin{array}{l}\text { Yes } \\
\%\end{array}$ & p-value * \\
\hline Gender & & & 0.059 \\
\hline Male & 80.4 & 19.6 & \\
\hline Female & 85.7 & 14.3 & \\
\hline Age (dichotomized by mean) & & & 0.476 \\
\hline 15 to 16 & 82.0 & 18.0 & \\
\hline 17 to 19 & 85.4 & 19.6 & \\
\hline Type of school & & & 0.138 \\
\hline Public & 84.1 & 15.9 & \\
\hline Private & 75.1 & 24.9 & \\
\hline Mother's schooling (years of study) & & & 0.273 \\
\hline 0 to 7 & 86.7 & 13.3 & \\
\hline 8 or more & 81.4 & 18.6 & \\
\hline Social Vulnerability Index & & & 0.044 \\
\hline High social vulnerability (Classes I and II) & 85.7 & 14.3 & \\
\hline Low social vulnerability (Classes III, IV and V) & 78.0 & 22.0 & \\
\hline
\end{tabular}

"Chi-square test. 
Table 4. Results of Poisson regression analysis regarding dependent variable (hazardous use to possible dependence) and independent variables among adolescents $(n=891)$, Belo Horizonte, Minas Gerais, Brazil, 2010.

\begin{tabular}{|c|c|c|c|c|}
\hline \multirow[b]{2}{*}{ Independent variables } & \multicolumn{4}{|c|}{ Hazardous use to possible dependence } \\
\hline & $\begin{array}{l}\text { Unadjusted RR } \\
\quad(95 \% \mathrm{CI})\end{array}$ & p-value ${ }^{*}$ & $\begin{array}{l}\text { Adjusted RR } \\
(95 \% \mathrm{CI})^{\mathrm{P}}\end{array}$ & p-value ${ }^{\mathrm{T}}$ \\
\hline \multicolumn{5}{|l|}{ Gender } \\
\hline Male & 1.0 & & 1.0 & \\
\hline Female & $0.74(0.54-1.01)$ & 0.061 & $0.75(0.54-1.0)$ & 0.05 \\
\hline \multicolumn{5}{|l|}{ Age } \\
\hline 15 to 16 years & 1.0 & & 1.0 & \\
\hline 17 to 19 years & $0.85(0.61-1.17)$ & 0.311 & $0.92(0.66-1.28)$ & 0.619 \\
\hline \multicolumn{5}{|l|}{ Mother's schooling } \\
\hline$\leq 7$ years of study & 1.0 & & 1.0 & \\
\hline$\geq 8$ years of study & $1.0(0.99-1.0)$ & 0.493 & $1.0(0.99-1.0)$ & 0.456 \\
\hline \multicolumn{5}{|l|}{ Type of school } \\
\hline Public & 1.0 & & 1.0 & \\
\hline Private & $1.27(0.88-1.83)$ & 0.207 & $1.6(0.71-1.59)$ & 0.763 \\
\hline \multicolumn{5}{|l|}{ Social Vulnerability Index } \\
\hline High social vulnerability (Classes I and II) & 1.0 & & 1.0 & \\
\hline Low social vulnerability (Classes III, IV and V) & $2.80(1.14-2.15)$ & 0.000 & $1.52(1.08-2.13)$ & $<0.001$ \\
\hline
\end{tabular}

RR: rate ratio; CI: confidence interval. ${ }^{c}$ chi-square test. ${ }^{\top}$ Adjusted for control variables (sex and age).

the consumption of alcohol among youths in Brazil continues to be a common practice. The prevalence of alcohol use in one's lifetime was high in the present study $(46.9 \%)$, in comparison with other studies ${ }^{2,28}$. An investigation carried out in the United States involving individuals aged 12 to 17 years found a $32.7 \%$ prevalence rate of alcohol use in the previous year ${ }^{2}$. In Brazil, the 5th National Survey on Psychotropic Drug Consumption, in which elementary and high school students were interviewed, found that initial experimentation occurred between the ages of 10 and 12 years and $41.2 \%$ of the adolescents reported alcohol consumption, demonstrating that prevention strategies should target 10 -year-olds ${ }^{28}$. Adolescence is a vulnerable period for the acquisition of habits, which can become lasting throughout life. The large exposure of adolescents to alcohol leads to higher chances of being involved in episodes of risk, such as problems with family, school and friends ${ }^{29}$.

A study using data from the Brazilian $\mathrm{Na}$ tional Alcohol Survey involving 761 participants aged 14 to 19 years reports that alcohol abuse/dependence and binge drinking are much higher in males than females. The authors suggest that, in such cases, alcohol disorder tends to emerge later in life and it would still be undetected among adolescents ${ }^{4}$. The greater occurrence of alcohol con- sumption among male adolescents in the present study is similar to findings reported in both national 4,14 and international studies.1,11 This may be related to historical and social aspects determined by the manner in which concepts of male and female behavior are constructed.1 According with the AUDIT, a score of 7 points or less denotes abstinence or low risk use; scores of 8 to 15 denotes hazardous use; scores of 16 to 19 denote harmful use and scores of 20 to 40 denote possible dependence ${ }^{20}$. In the present study, the score was dichotomized and, based on the original instrument ${ }^{20}$, the cutoff point of 7 was adopted, 7 points or less (abstinence or the low risk use) and 8 points or more (harmful use to possible dependence). The identification of adolescents who use harmful form of alcohol or may already be dependent on alcohol is important so that public policies are developed. One hundred fifty-nine students (16.4\%) demonstrated hazardous use to possible dependence. This figure is higher than that reported in other Brazilian studies employing the AUDIT screening tool. A study carried out with high school students, aged 13 to 29 years, in the city of Passos (state of Minas Gerais) reports a 3.51\% prevalence rate of hazardous drinking behavior and a $3.31 \%$ prevalence rate of possible dependence ${ }^{30}$. Magnabosco et al. ${ }^{31}$, in a study with 
participants aged 11 and above, found that 3.8\% of the individuals interviewed exhibited alcohol intake frequency levels suggestive of dependence. The literature has indicated the importance of environmental and psychosocial factors on alcohol consumption among adolescents. Reducing alcohol use in adolescents may involve reducing exposure to these risk factors ${ }^{3}$. The strong association between frequent teen drinking and alcohol dependence in adulthood may reflect an already existent dependence syndrome in adolescence? Adolescent alcohol use may contribute to the development of health and social inequalities during the transition from adolescence to adulthood and it is a risk behaviour associated with significant later adversity and social exclusion. 11 In a longitudinal birth cohort, with the total of 11,622 British subjects at age 16 years and 11 261 subjects at age 30 years, $17.7 \%$ of participants reported binge drinking in the previous 2 weeks at the age of 16 years. Adolescent alcohol consumption predicted an increased risk of adult alcohol dependence (OR 1.6, 95\% CI 1.3 to 2.0), excessive regular consumption (OR 1.7, 95\% CI 1.4 to 2.1$)^{11}$. Frequent regular drinking provides a higher adult risk of alcohol use problems, as alcohol dependency/abuse and excessive regular alcohol consumption ${ }^{11}$. A cohort study, conducted in a sample of almost two thousand individuals followed from ages 14-15 to 20-21 years, suggested that an increase in alcohol consumption behaviour during adolescence is associated with an increased risk of alcohol abuse/dependence ${ }^{9}$.

The occasional consumption can also expose adolescents to other problems such as traffic accidents, sexual risk behavior (sexually transmitted diseases and unwanted pregnancy), violence, unintentional injuries and academic problems?. Prolonged use can lead to suicide or chronic disease, such as mental disorders, cancer, high blood pressure, obesity, stroke, polyneuropathy, dementia, seizures and tumors of the digestive tract. The adolescents in the present study reported problems related to alcohol consumption and the most frequent of which were an inability to recall something and feelings of guilt or remorse after drinking.

According to Pechansky et al. ${ }^{32}$ alcohol causes neurochemical alterations associated with cognitive skills and behavior, with a negative impact on memory, learning and the control of impulses. Alcohol consumption in adolescence is also associated with a series of academic problems that may stem from memory deficits: adolescents with alcohol dependence have more diffi- culty remembering words and simple geometric drawings after a 10-minute interval in comparison to those without alcohol dependence ${ }^{33}$. Assanangkornchai et $\mathrm{al}^{34}$ found that the main problem among male adolescents was initiating fights when drinking (26.1\%), whereas the main problem among female adolescents was feelings of guilt or remorse after drinking alcoholic beverages (17.5\%). Excessive alcohol consumption has considerable potential to influence of aspects of development and mental health among adolescents, such as the stage of puberty, depression, anxiety and excessive daytime sleepiness. Among adolescents who reported consequences of alcohol consumption, once a week to nearly every day, this study reported the inability to recall something after drinking (18.6\%) and a feeling of guilt or remorse for having drunk $(28.7 \%)$ and suggests a prospective cohort to infer possible consequence in the future.

Adolescents do not necessarily take into consideration the seriousness of problems stemming from alcohol use. For instance, according to a previous study ${ }^{32}, 50 \%$ of youths who drank regularly reported that the main negative consequence was improper behavior during or after drinking or failure to perform tasks that were expected of them (cited by $8.0 \%$ of the present sample); $33 \%$ reported difficulty remembering something (cited by $15.4 \%$ of the present sample) and only $20 \%$ cited drunk driving as a problem stemming from alcohol use, despite the fact that automobile accidents involving a drunk driver are the major cause of death in this age group ${ }^{32}$. In our study, only $7.4 \%$ of the sample reported having caused injury or harm to themselves or others due to the consumption of alcoholic beverages.

Even without a diagnosis of alcohol abuse or dependence, harm can stem from use if an adolescent feels more confident with regard to resolving situations and taking initiative only under the effects of alcohol ${ }^{11}$. Many adolescents associate recreation with alcohol consumption and often need to drink at the end of the day in order to feel better. Thus, such individuals learn to develop skills only with the use of alcohol and feel incapable of performing these activities when alcohol is not available, which is a form of dependence ${ }^{11}$. Viner and Taylor ${ }^{11}$ report that heavy drinking can have a negative impact on health and contributes toward social inequalities during the transition from adolescence into adulthood.

In the present investigation, adolescents categorized in social classes III, IV and V (low social vulnerability) were more likely to exhibiting 
hazardous use to possible dependence than those categorized in classes I and II (high social vulnerability). This result is in disagreement with findings described in previous studies, which report that individuals with less buying power consume more alcohol in both adolescence and adulthood $^{16}$, as well as, other study carried out in the city of Pelotas (state of Rio Grande do Sul, Brazil) involving 2177 individuals where those from lower economic classes had a nearly threefold greater prevalence rate of alcohol abuse ${ }^{15}$. However, Baus et al. ${ }^{12}$ found that the students in elementary and high school with a higher socioeconomic status had a twofold greater risk of alcohol use than those with a lower socioeconomic status and hypothesized that economic and cultural determinants may be related to the profusion of "beer parties" and the price of alcoholic beverages, as well as, Guimarães et al. ${ }^{14}$ identified a greater availability of financial resources (socioeconomic level and work) as a facilitating factor regarding alcohol consumption. As the SVI includes an assessment of both household income and education, these results must be related to disposable income among those who live in less vulnerable areas, allowing adolescents to buy their own alcohol and consume greater amounts. Higher economic class teenagers usually receive monthly allowances, which allows them to buy own alcohol for consumption. Along with this fact, Belo Horizonte is considered the world capital of the bars and, culturally, adolescents consume more alcoholic drinks, since one of the forms of socialization is the encounter between pairs in bars.

The present study has limitations that should be considered. There may have been information bias related to memory errors. However, self-administered questionnaires generally allow participants to feel more at ease when responding to questions, especially those addressing information considered private or shameful. Another limitation regards school policies in relation to alcohol consumption, which were not investigated during the data acquisition. A school constitutes a functional community with social support relationships that share values and norms. Social participation in school activities may moderate individual risk with regard to initiating adverse health behavior, such as excessive alcohol intake ${ }^{35}$. A third limitation of the present study is the cross-sectional design, which only allows the detection of associations and does not per- mit the determination of causality. Thus, longitudinal studies are needed to allow more specific analyses regarding drinking patterns as well as the evaluation of hazardous use to dependence among adolescents in the city of Belo Horizonte and the possible long-term consequences. Finally, the study did not include other tests, such as urine ${ }^{36}$ or saliva ${ }^{37}$ for identification of alcohol consumption, which could lead to under or over notifications.

\section{Conclusions}

The findings of the present study demonstrate a high prevalence rate of alcohol consumption as well as hazardous use to possible dependence among the participants. The most frequent consequences of alcohol use were an inability to recall events after drinking and feelings of guilt or remorse for having drunk. Hazardous use to possible dependence was significantly associated with the male gender and low social vulnerability (better socioeconomic status).

Knowledge of the relationship between socioeconomic status and alcohol use during adolescence is of great importance, since the findings are controversial. Given that alcohol consumption is a potential health hazard, and it is possible that this behavior be continued in adulthood, it is important to establish the factors associated with alcohol use so that can contribute to the implementation of more effective public health policies.

\section{Collaborations}

JG Martins-Oliveira, KO Jorge, EF Ferreira and PM Zarzar conceptualized the study. KO Jorge collected the data. JG Martins-Oliveira drafted the first version. RC Ferreira conducted the analysis. RC Ferreira and PM Zarzar contributed substantially to the interpretation of the findings. KO Jorge, RC Ferreira, EF Ferreira, MP Vale and PM Zarzar revised the manuscript for important intellectual content. All authors read and approved the final version of the manuscript. 


\section{References}

1. Maldonado-Devincci AM, Badanich KA, Kirstein CL. Alcohol during adolescence selectively alters immediate and long-term behavior and neurochemistry. Alcohol 2010; 44(1):57-66.

2. Wu LT, Schlenger WE, Galvin DM. The relationship between employment and substance use among students aged 12 to 17. J Adolesc Health 2003; 32(1):5-15.

3. Barbosa Filho VC, Campos WD, Lopes Ada S. Prevalence of alcohol and tobacco use among Brazilian adolescents: a systematic review. Rev Saude Publica 2012; 46(5):901-917.

4. Madruga CS, Laranjeira R, Caetano R, Pinsky I, Zaleski $\mathrm{M}$, Ferri CP. Use of licit and illicit substances among adolescents in Brazil - a national survey. Addict Behav 2012; 37(10):1171-1175.

5. Miller JW, Naimi TS, Brewer RD, Jones SE. Binge drinking and associated health risk behaviors among high school students. Pediatrics 2007; 119(1):76-85.

6. Pulcherio G, Bastos T, Strey M, Boni R. Consumo de álcool entre adolescentes do sexo feminino. Rev Psiq Clín 2011; 38(5):209-210.

7. World Health Organization (WHO). International Classification of Diseases (ICD). [Cited 2 Nov 2014]. Available at: http://www.who.int/classifications/icd/en/

8. Hasin D. Classification of alcohol use disorders. National Institute on Alcohol Abuse and Alcoholism, 2003. [Cited 5 Dec 2014]. Available at: http://pubs. niaaa.nih.gov/publications/arh27-1/5-17.htm

9. Bonomo YA, Bowes G, Coffey C, Carlin JB, Patton GC. Teenage drinking and the onset of alcohol dependence: a cohort study over seven years. Addiction 2004; 99(12):1520-1528.

10. Vieira DL, Ribeiro M, Romano M, Laranjeira RR. Álcool e adolescentes: estudo para implementar políticas municipais. Rev Saude Publica 2007; 41(3):396-403.

11. Viner RM, Taylor B. Adult outcomes of binge drinking in adolescence: findings from a UK national birth cohort. J Epidemiol Community Health 2007; 61(10):902907.

12. Baus J, Kupek E, Pires M. Prevalência e fatores de risco relacionados ao uso de drogas entre escolares. Rev Saude Publica 2002; 36(1):40-46.

13. Zarzar PM, Jorge KO, Oksanen T, Vale MP, Ferreira EF, Kawachi I. Association between binge drinking, type of friends and gender: A cross-sectional study among Brazilian adolescents. BMC Public Health 2012; 12:257.

14. Guimarães JL, Godinho PH, Cruz R, Kappann JI, Tosta Junior LA. Consumo de drogas psicoativas nos adolescentes escolares de Assis, SP. Rev Saude Publica 2004; 38(1):130-132.

15. Costa JSD, Silveira MF, Gazalle FK, Oliveira SS, Hallal PC, Menezes AMB, et al. Consumo abusivo de álcool e fatores associados: estudo de base populacional. Rev Saude Publica 2004; 38(2):284-291.

16. Mendonça-Sassi RA, Béria JU. Prevalence of alcohol use disorders and associated factors: a populationbased study using AUDIT in southern Brazil. Addiction 2003; 98(6):799-804.

17. Brazilian Institute of Geography and Statistics (IBGE): 2010 population census. [Cited $14 \mathrm{Feb} 2014$ ]. Available at: http://www.ibge.gov.br/home/estatistica/populacao /belohorizonte
18. Instituto Nacional de Estudos e Pesquisas Educacionais Anísio Teixeira. (2010). Sistema de Consulta a Matrícula do Censo Escolar - 1997 a 2010. [Cited 5 Dec 2014]. Available at: http://portal.inep.gov.br/basica-censo-escolar-matricula

19. Pearce N. Effect measures in prevalence studies. Environ Health Perspect 2004; 112:1047-1050.

20. Lima CT, Freire AC, Silva AP, Teixeira RM, Farrell M, Prince M. Concurrent and construct validity of the AUDIT in an urban Brazilian sample. Alcohol Alcohol 2005; 40(6):584-589.

21. Babor TF, Higgins-Biddle JC, Saunders JB, Monteiro MG. The alcohol use disorders identification test guidelines for use in primary care, $2 \mathrm{edn}, 2001$. [Cited 5 Dec 2014]. Available at: http://whqlibdoc.who.int/ hq/2001/who_msd_msb_01.6a.pdf

22. Belo Horizonte City Hall (PBH). The Social Vulnerability Index. (2009). [Internet]. [Cited 2009 Aug 23]. Available at: http://www.portal2.pbh.gov.br/pbh/index .html.

23. Nahas MI, Ribeiro C, Esteves O, Moscovitch S, Martins VL. O mapa da exclusão social de Belo Horizonte: metodologia de construção de um instrumento de gestão urbana. Cad Cienc Soc 2000; 7(10):75-88.

24. Melotti R, Heron J, Hickman M, Macleod J, Araya R, Lewis G. Adolescent alcohol and tobacco use and early socioeconomic position: the ALSPAC birth cohort. Pediatrics 2011; 127(4):948-955.

25. Oliveira Filho PM, Jorge KO, Ferreira EF, Ramos-Jorge ML, Tataounoff J, Zarzar PM. Association between dental trauma and alcohol use among adolescents. Dent Traumatol 2013; 29(5):372-377.

26. Piovesan C, Pádua MC, Ardenghi TM, Mendes FM, Bonini GC. Can type of school be used as an alternative indicator of socioeconomic status in dental caries studies? A cross-sectional study. BMC Med Res Methodol 2011; 11:37.

27. Brasil. Lei no 9.294 de 15 de julho de 1996. Dispõe sobre as restrições ao uso e à propaganda de produtos fumígeros, bebidas alcoólicas, medicamentos, terapias e defensivos agrícolas, nos termos do parágrafo 4 o do artigo 220 da Constituição Federal. Diário Oficial da União 1996; 16 jul.

28. Galduroz JCF, Noto AR, Fonseca AM, Carlini EA. V Levantamento Nacional sobre o Consumo de Drogas Psicotropicas entre Estudantes do Ensino Fundamental e Medio da Rede Publica de Ensino nas 27 Capitais Brasileiras. Sao Paulo: Centro Brasileiro de Informacoes sobre Drogas Psicotropicas (CEBRID), Secretaria Nacional Antidrogas (SENAD); 2004.

29. Malta DC, Mascarenhas MDM, Porto DL, Duarte EA, Sardinha LM, Barreto SM, Morais Neto OL. Prevalência do consumo de álcool e drogas entre adolescentes: análise dos dados da Pesquisa Nacional de Saúde Escolar. Rev Bras Epidemiol 2011; 14(1):136-146.

30. Campos JA, Almeida JC, Garcia PP, Faria JB. Consumo de álcool entre estudantes do ensino médio do município de Passos - MG. Cien Saude Colet 2011; 16(12):4745-4754. 
31. Magnabosco MB, Formigoni MLOS, Ronzani TM. Avaliação dos padrões de uso de álcool em usuários de serviços de Atenção Primária à Saúde de Juiz de Fora e Rio Pomba (MG). Rev Bras Epidemiol 2007; 10(4):637-647.

32. Pechansky F, Szobot CM, Scivoletto S. Uso de álcool entre adolescentes: conceitos, características epidemiológicas e fatores etiopatogênicos. Rev Bras de Psiquiatr 2004; 26(1):14-17.

33. Brown SA, Tapert SF, Granholm E, Delis DC. Neurocognitive functioning of adolescents: effects of protracted alcohol use. Alcohol Clin Exp Res 2000; 24(2):164-171.

34. Assanangkornchai S, Sam-Angsri N, Rerngpongpan S, Lertnakorn A. Patterns of Alcohol Consumption in the Thai Population: Results of the National Household Survey of 2007. Alcohol and Alcohol 2010; 45(3):278285

35. Weitzman E, Kawachi I. Giving means receiving: the protective effect of social capital on binge drinking on college campuses. Am J Public Health 2000; 90(12):1936-1939.

36. Nicolson NG, Lank PM, Crandall ML. Emergency department alcohol and drug screening for Illinois pediatric trauma patients, 1999 to 2009. Am J Surg 2014; 208(4):531-535.

37. Langel K, Gunnar T, Ariniemi K, Rajamäki O, Lillsunde P. A validated method for the detection and quantitation of 50 drugs of abuse and medicinal drugs in oral fluid by gas chromatography-mass spectrometry. J Chromatogr B Analyt Technol Biomed Life Sci 2011; 879(13-14):859-870.

Artigo apresentado em 03/02/2015

Aprovado em 18/03/2015

Versão final apresentada em 20/03/2015 